\title{
CRITICAL THINKING AS AN EDUCATIONAL OBJECTIVE IN A GLOBAL INFORMATION SOCIETY
}

\author{
Anna Mróz \\ Pedagogical University of Cracow, Poland \\ Iwona Ocetkiewicz \\ Pedagogical University of Cracow, Poland \\ Katarzyna Walotek-Ściańska \\ Jesuit University Ignatianum in Krakow, Poland
}

\begin{abstract}
Critical thinking is defined as the competency for the future, which is crucial for every its member responsible participation in the global information society. Today, possessing this competence often determines how one perceives the reality and responds appropriately to the stimuli of the surrounding world. This competency should be shaped (created) by teachers, especially within the process of formal education. Teachers should choose specific methods and forms of work, the aim of which is to develop the components of the competency to think critically. The paper is a presentation of the results of research that aimed to examine the methods and forms of teachers' effort and work that create the critical thinking competency in students at the third (junior high school) and the fourth (high school) stages of education. Throughout the study, the authors sought an answer to the question: what methods and forms of education are used by teachers at the third and fourth stages of education to shape the critical thinking competency? The research was carried out using the quantitative approach. The research method was a survey and convenience sampling was used to select subjects. 337 Polish teachers participated in the study. The analysis of the results of the research suggests that Polish teachers are not sufficiently prepared to develop the critical thinking competency in their students. They lack methodological competencies at an appropriate level and are not even aware of the need for developing critical thinking in many cases.
\end{abstract}

Keywords: critical thinking, teacher, methods of teaching, organizational forms of teaching.

\section{Introduction}

Modern complex social, ethical, political, economic, or educational issues people have to face need to be approached with reflection, in-depth analysis, and multiple perspectives. This category of problems: multi-context, multi-faceted, open, complex, and ambivalent problems is the central interest of advocates of critical thinking teaching. It is clear the judgments made about such problems may be contrasting because they may be approached with different assumptions, goals, understanding of ideas, or even different systems of values. Critical thinkers 
should understand and take into consideration this complexity and interdependence of various factors. What is more, they should reach their judgments by themselves (Wasilewska-Kamińska, 2016: 95).

In her analysis of the notion of critical thinking in the cognitive setting, Iwona Czaja-Chudyba found it to be a type of realistic thinking aimed to thoroughly evaluate significant aspects of human intellectual activity in the form of a metacognitive process (Czaja-Chudyba, 2013: 26). Richard Paul and Linda Edler defined critical thinking in a similar manner. They considered it an art of analysing and evaluating thinking in order to improve it. Krystyna GórniakKocikowska believed that Critical thinking is an intellectually disciplined process of active and competent conceptualisation, application, analysis, synthesis, and/or evaluation of information collected or created through observation, experience, deliberation, thinking, or communication that acts as a guide for beliefs and actions. Its model prototype is based on universal intellectual values that [...] surpass academic divisions (Górniak-Kocikowska, 2014: 20-23).

In his search for neurobiological bases of critical thinking, Stefan Florek noted that from the evolutionary perspective, the areas of the cortex linked to critical thinking are a relatively new addition to the neuronal portfolio of Homo sapiens. The ability to think rationally has developed as a form of adaptation to solving problems typical of the natural and social living environment of huntergatherers. Thus, it often fails in technologically modified environments. This phenomenon is referred to as the evolutionary lag (Florek, 2012: 130). This means that the care for the development of critical thinking competencies, in particular in young people, becomes an especially important issue in light of the omnipresence of technology.

Richard Paul and his Critical thinking Movement fellows propose to define critical thinking as a progressive process whereby an individual continually and dynamically improves their reasoning through the application and self-imposition of intellectual standards (active and appropriate conceptualisation, application, analysis, synthesis, and evaluation of information derived from observation, experience, reflection, reasoning, and communicating as a method of activity). According to the Critical Thinking Movement, critical thinking is a deliberate, rational, and well-directed reasoning whereby the probability or reaching the intended result is increased by using cognitive skills or strategies. This type of thinking should be clear, precise, accurate, in-depth, open, logical, meaningful, objective, and not lacking in intellectual integrity of every-day life. It is a selfdirecting, self-monitoring, self-disciplining, and self-correcting mode of thinking. It is a process where one poses questions about oneself and the surroundings (Czaja-Chudyba, 2013: 47). Paul and Edler argue that critical thinkers make effort to live rationally, reasonably, and empathically. They are sensitive to the unpredictable nature of human thinking, which is often unconscious. They strive 
to reduce the force of their egocentric and sociocentric habits and employ intellectual tools from the critical thinking toolbox: notions and principles that let them analyse, evaluate, and improve the way they think. They work hard to develop their intellectual virtues such as integrity, humility, kindness, empathy, sense of justice, and trust in reason. They are aware that however skilled thinkers they are, they can always improve their logical thinking skills and they sometimes may fall prey to fallacies, human irrationality, bias, cognitive distortions, disruptions, slavish following of social principles and taboos, or self-interest. Critical thinkers wish to improve the world in order to contribute to the construction of a more rational and civilised society while recognising the complexity of problems they tackle. They try to avoid simplification and strive for determination of real rights and needs of other people. They share Socrates's belief: 'The unexamined life is not worth living' because they know that a world where people lead unexamined lives is an uncritical, unjust, dangerous world (Paul \& Edler, 2006).

Joanne Kurfiss noted that critical thinking is a method of problem-solving and the main difference between the two is that the critical thinking competency means reasoning concerned with problems that are open, complex, and unspecific, for which there is no single solution. Therefore, the objective of critical analysis is not to find and apply a specific solution but to present a problem and then develop, and share a reliable and acceptable stance through argumentation (Paul \& Edler, 2006).

Critical and independent thinking competencies can be learned only through giving up on the traditional, adaptive approach to the educational process (Muchacka, 2007: 31). It is, therefore, necessary to change the expository approach to teaching into the constructivist or connectivist methods. In the constructivist model, the learning motivation comes from the innate curiosity of every student and the satisfaction is related to solved problems or the search for solutions itself. The reward the behaviourists stress is just an addition. From the point of view of the cognitive concept, the appropriate methods are problemsolving and active learning. Moreover, to implement the constructivist and connectivist methods, the school has to provide appropriate equipment with the right teaching aids, including media available to students (Strykowski, 2007: 31-37). Constructivism involves providing students with appropriate conditions for independent learning: posing questions, providing sources of information, and managing knowledge. The teacher shares the responsibility for effects of the education with the student (Dylak, 2009: 41). In the constructivist teaching process, the role of teacher, who should have reflective and critical competencies, is important. The constructivist, critical discussion is based on a prior assessment by the teacher of the discrepancy between student's knowledge and the official knowledge in the syllabus. The task of the teacher in the constructivist approach 
is to find out what the student finds interesting and develop ways to use it to stimulate student's cognitive activity, for example, through untypical questions, unstructured information, inspiration to formulate and verify hypotheses, fostering independence; to allow students to assume responsibility, introduce them into the world of contradictions through situations and experience that negate past assumptions of the students (Czaja-Chudyba, 2013: 43-44).

Words of Ewa Wasilewska-Kamińska are a precise summary of the critical thinking competency, which is an intentional, self-regulating judgement resulting in the interpretation, evaluation, and conclusions. It is further an explanation of proof, notions, methods, context, or criteria the judgement was based on. [...] [It is] the key tool for investigation and as such it is an empowering force in the educational process and an abundant source in thepersonal civil life of an individual. [...] The model critical thinker: is inquisitive and well-informed, trusts the reason, is open-minded, flexible, unbiased, and careful in judgement, and aware of own bias, ready to reconsiders issues, clear, thorough in searching for reliable information, reasonable in the selection of criteria, focused in investigation, and strives to achieve results adequate to the matter and circumstances (Wasilewska-Kamińska, 2016: 101).

Education of critical thinkers entails effort aimed to achieve this ideal. To this end, teachers should employ active-learning and problem-solving methods because the competency is acquired and developed in action and through action.

The purpose of the article is to present research results. The main goal of the study was to explore and to describe educational methods and forms which Polish teachers use to create the competence of critical thinking. The method of the survey was used during the research (quantitative research in nomothetic paradigm).

\section{Methodological assumptions of own research}

The research employed the quantitative paradigm. Its objective was to explore- and describe (Babbie, 2013) teaching methods and forms used by teachers at the third (junior high school) and the fourth (high school) stages of education in order to support acquisition and development (shaping) of critical thinking competencies in students. The research focused on educational methods and forms used by teachers that they believe shape critical thinking.

The primary problem is the: question what educational methods and forms teachers use to shape critical thinking in their students? Data for the research was collected using a poll. The survey employed a survey questionnaire prepared by the authors.

The sample was selected by convenience sampling (Christensen \& Johnson, 2012). The study involved 337 teachers of core courses. 
SOCIETY. INTEGRATION. EDUCATION

Proceedings of the International Scientific Conference. Volume II, May $25^{\text {th }}-26^{\text {th }}$, 2018. 342-351

\section{Critical thinking as an educational objective based on a survey result analysis}

As the analysis of the research showed, the educational method most often used by the subjects to shape critical thinking was brainstorming. The total of $46 \%$ subjects used it with $35 \%$ using it very often. Relatively often used methods included text work (used very often by $19 \%$ ), talk (very often: $17.8 \%$ ), curriculum discussion (very often: $16.9 \%$ ), problem-focused lecture (very often: $16.3 \%$ ), traditional problem method (very often: $15.1 \%$ ), and practical classes (very often $15.1 \%$ ). Other methods were used by less than $20 \%$ of the subjects. The least often used methods were planning methods and techniques, laboratory method, Webquest, and performing arts. They were indicated by less than $4 \%$ of the subjects.

Table 1 Educational methods most often used by the subjects to create critical thinking competencies

\begin{tabular}{|c|c|c|c|c|c|c|c|c|c|c|}
\hline \multirow{2}{*}{$\begin{array}{l}\text { Methods } \\
\text { employed to } \\
\text { create critical } \\
\text { thinking }\end{array}$} & \multicolumn{2}{|c|}{ very often } & \multicolumn{2}{|c|}{ sometimes } & \multicolumn{2}{|c|}{ occasionally } & \multicolumn{2}{|c|}{ not used } & \multicolumn{2}{|c|}{ total } \\
\hline & $\mathbf{N}$ & $\%$ & $\mathbf{N}$ & $\%$ & $\mathbf{N}$ & $\%$ & $\mathbf{N}$ & $\%$ & $\mathbf{N}$ & $\%$ \\
\hline Description & 11 & 3.26 & 5 & 1.48 & 3 & 89 & 318 & 94.37 & 337 & 100 \\
\hline Story & 13 & 3.86 & 6 & 1.78 & 7 & 2.09 & 311 & 92.27 & 337 & 100 \\
\hline Talk & 60 & 17.80 & 25 & 7.42 & 8 & 2.37 & 244 & 72.41 & 337 & 100 \\
\hline Formal lecture & 29 & 8.61 & 6 & 1.78 & 5 & 1.48 & 297 & 88.13 & 337 & 100 \\
\hline $\begin{array}{l}\text { Problem-focused } \\
\text { lecture }\end{array}$ & 55 & 16.32 & 22 & 6.53 & 14 & 4.15 & 246 & 73.00 & 337 & 100 \\
\hline Explanation & 19 & 5.64 & 7 & 2.08 & 8 & 2.37 & 303 & 89.91 & 337 & 100 \\
\hline Text work & 64 & 18.99 & 27 & 8.01 & 11 & 3.26 & 235 & 69.74 & 337 & 100 \\
\hline $\begin{array}{l}\text { Traditional } \\
\text { problem method }\end{array}$ & 51 & 15.14 & 18 & 5.34 & 12 & 3.56 & 256 & 75.96 & 337 & 100 \\
\hline Brainstorming & 118 & 35.01 & 27 & 8.01 & 10 & 2.97 & 182 & 54.01 & 337 & 100 \\
\hline Case method & 20 & 5.93 & 21 & 6.23 & 10 & 2.97 & 286 & 84.87 & 337 & 100 \\
\hline Simulation & 13 & 3.86 & 23 & 6.82 & 10 & 2.97 & 291 & 86.35 & 337 & 100 \\
\hline Enactment & 9 & 2.67 & 13 & 3.86 & 10 & 2.97 & 305 & 90.50 & 337 & 100 \\
\hline $\begin{array}{l}\text { Curriculum } \\
\text { discussion }\end{array}$ & 57 & 16.91 & 32 & 9.50 & 15 & 4.45 & 233 & 69.14 & 337 & 100 \\
\hline Research method & 17 & 5.04 & 12 & 3.56 & 12 & 3.56 & 296 & 87.84 & 337 & 100 \\
\hline Drama & 12 & 3.56 & 9 & 2.67 & 15 & 4.45 & 301 & 89. & 337 & 100 \\
\hline Performing arts & 0 & 0.00 & 2 & 59 & 9 & 2.67 & 326 & 96.73 & 337 & 100 \\
\hline Exhibition & 1 & 30 & 6 & 1.78 & 8 & 2.37 & 322 & 95.55 & 337 & 100 \\
\hline Display/film & 17 & 5.04 & 26 & 7.72 & 20 & 5.93 & 274 & 81.31 & 337 & 100 \\
\hline Practical classes & 51 & 15.13 & 13 & 3.86 & 5 & 1.48 & 268 & 79.53 & 337 & 100 \\
\hline $\begin{array}{l}\text { Laboratory } \\
\text { method }\end{array}$ & 10 & 2.97 & 1 & 30 & 1 & 30 & 325 & 96.43 & 337 & 100 \\
\hline
\end{tabular}


Mróz et al., 2018. Critical Thinking as an Educational Objective in a Global Information Society

\begin{tabular}{|l|l|l|l|l|l|l|l|l|l|l|}
\hline Measurement & 3 & 89 & 6 & 1.78 & 7 & 2.08 & 321 & 95.24 & 337 & 100 \\
\hline $\begin{array}{l}\text { Guiding text } \\
\text { method }\end{array}$ & 8 & 2.37 & 8 & 2.37 & 3 & 89 & 318 & 94.36 & 337 & 100 \\
\hline Individual project & 15 & 4.45 & 21 & 6.23 & 6 & 1.78 & 295 & 87.54 & 337 & 100 \\
\hline Group project & 9 & 2.67 & 27 & 8.01 & 18 & 5.34 & 283 & 83.98 & 337 & 100 \\
\hline $\begin{array}{l}\text { Integration } \\
\text { methods }\end{array}$ & 3 & 89 & 10 & 2.97 & 7 & 2.08 & 317 & 94.05 & 337 & 100 \\
\hline $\begin{array}{l}\text { Creative problem } \\
\text { solving }\end{array}$ & 30 & 8.90 & 17 & 5.05 & 11 & 3.26 & 279 & 82.79 & 337 & 100 \\
\hline $\begin{array}{l}\text { Planning } \\
\text { methods and } \\
\text { techniques }\end{array}$ & 6 & 1.78 & 3 & 89 & 4 & 1.18 & 324 & 96.14 & 337 & 100 \\
\hline $\begin{array}{l}\text { Hierarchisation } \\
\text { methods }\end{array}$ & 11 & 3.26 & 16 & 4.75 & 4 & 1.19 & 306 & 90.80 & 337 & 100 \\
\hline $\begin{array}{l}\text { Evaluation } \\
\text { methods }\end{array}$ & 8 & 2.37 & 13 & 3.86 & 6 & 1.78 & 310 & 91.99 & 337 & 100 \\
\hline $\begin{array}{l}\text { Cooperation- } \\
\text { based methods }\end{array}$ & 13 & 3.86 & 14 & 4.15 & 0 & 0.00 & 310 & 91.99 & 337 & 100 \\
\hline $\begin{array}{l}\text { Joint decision- } \\
\text { making }\end{array}$ & 5 & 1.48 & 8 & 2.37 & 3 & 89 & 321 & 95.25 & 337 & 100 \\
\hline $\begin{array}{l}\text { Creating and } \\
\text { defining notions }\end{array}$ & 13 & 3.86 & 8 & 2.37 & 7 & 2.08 & 309 & 91.69 & 337 & 100 \\
\hline $\begin{array}{l}\text { Diagnostic } \\
\text { methods and } \\
\text { techniques }\end{array}$ & 14 & 4.15 & 2 & 59 & 10 & 2.97 & 311 & 92.28 & 337 & 100 \\
\hline $\begin{array}{l}\text { Creative thinking } \\
\text { development }\end{array}$ & 25 & 7.42 & 21 & 6.23 & 9 & 2.67 & 282 & 83.68 & 337 & 100 \\
\hline Webquest \\
\hline $\begin{array}{l}\text { Portfolio } \text { E- } \\
\text { portfolio }\end{array}$ & 2 & 0.59 & 4 & 1.19 & 6 & 1.78 & 325 & 96.44 & 337 & 100 \\
\hline SWOT analysis & 14 & 4.15 & 23 & 6.82 & 25 & 7.43 & 275 & 81.60 & 337 & 100 \\
\hline Mindmap & 23 & 6.83 & 11 & 3.26 & 8 & 2.37 & 295 & 87.54 & 337 & 100 \\
\hline $\begin{array}{l}\text { Educational } \\
\text { project } \\
\text { Metaplan }\end{array}$ & 9 & 2.67 & 16 & 4.75 & 19 & 5.64 & 293 & 86.94 & 337 & 100 \\
\hline
\end{tabular}

An analysis of the results has shown that the selection of educational methods aimed at developing critical thinking is influenced the most by the particular subject taught (Fig. 1.). Polish language teachers most often selected brainstorming (46.67 \%), then text work (31.67\%), curriculum discussion (30\%), and traditional problem method (21.67 \%). These are problem-based methods. When used right, they may shape the critical thinking competency. It is, however, disturbing that many teachers indicated talk as a method of developing critical thinking (18.33\%). Teachers of the Polish language rarely use active-learning methods to create this competency. The most often indicated active-learning 
method was creative problem solving (only $8.33 \%$ ), which is very valuable for critical thinking. It is also surprising that they do not use exhibition methods to create this competency. The drama was used very often by only $11 \%$ and often by $8.33 \%$. Other exhibition methods were used by less than $6 \%$ of the subjects in aggregate. Similarly, less than $12 \%$ of the subjects indicated the frequent use of SWOT analysis as a method for shaping critical thinking. Note that Polish language teachers have the greatest number of teaching hours per week (5 or more) and the factual content of the subject is very broad. They could be expected to demonstrate the greatest variety of methods used to develop critical thinking.

Similar results were obtained for teachers of humanities and social subjects. Less than $20 \%$ of history, civics, culture studies, and entrepreneurship teachers declared using talk as a method of developing critical thinking. About $15 \%$ of the subjects use curriculum discussion to this end (14.93\%). The teachers did not use exhibition methods and rarely used active-learning methods (like Polish language teachers, they use mainly creative problem solving, $8.96 \%$ very often).

Among foreign language teachers, just as with Polish language teachers and humanities and social studies teachers, the dominant method for shaping critical thinking was brainstorming (35.14 \% of cases). It is alarming that a little over 20 $\%$ of them declared talk as the method they use to develop critical thinking in their students. This group of teachers favours text work and practical classes (16.22 \%) probably due to the nature of foreign language teaching. It should be added that these teachers may choose texts and exercises rather freely. The right selection can develop critical thinking in students and help the teacher build knowledge and attitudes favouring sustainable development. Similarly to Polish language teachers and other humanities teachers, they did not employ active-learning and exhibition methods with the exception of creative problem solving, which was used often by only $8.11 \%$ of the subjects.

Results for mathematicians are different. Owing to the specific nature of teaching mathematics, they used the traditional problem method (30.56\%), problem-focused lecture (27.78 \%) and practical classes (27.78 \%) more often than humanities teachers. Still, talk (25\%) and brainstorming (30.56 \%) are popular in this group as well.

Teachers of science subjects most often used brainstorming $(27.91 \%)$, curriculum discussion (16.28 \%), problem-focused lecture (15.12 \%), and the traditional problem method (13.95\%). 


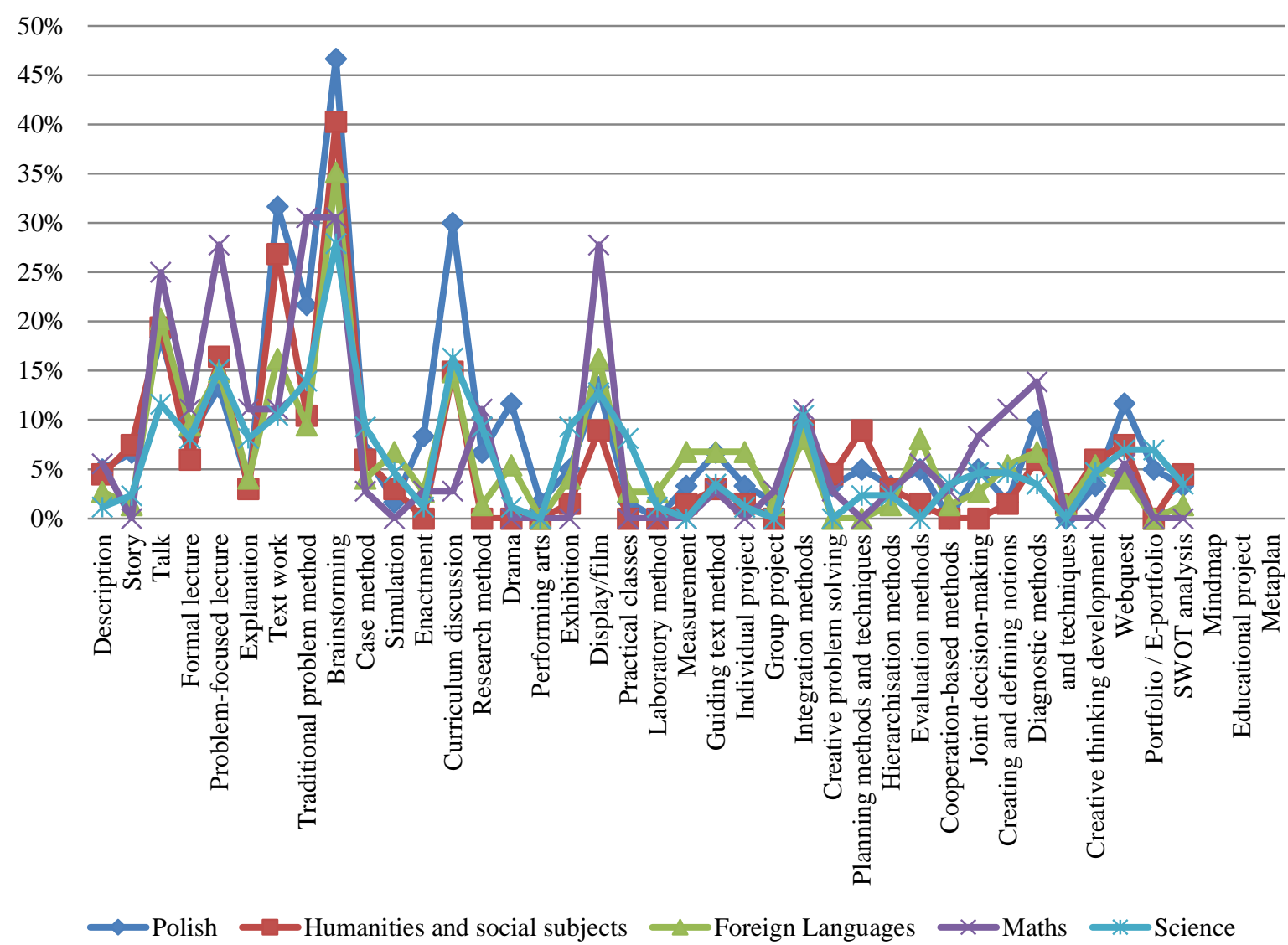

Figure 1. Educational methods most often used by teachers of individual subjects to create critical thinking competencies

To sum up, the teachers preferred traditional methods of instruction from the expository and problem groups of methods to create critical thinking in their students. They did not use active-learning, exhibitory, or modern methods such as Webquest or mind map. They avoided projects, both individual and group ones. What is more, they did not carry out educational projects, which may develop critical thinking in students. The analysis of the results has demonstrated that the selected methods for developing the critical thinking competency did not depend on the place of work, type of school, professional experience, or rank of the teacher.

The most often used educational forms aimed to shape critical thinking were individual work and group work (Fig. 2). Individual work was used very often by $38.3 \%$ of the subjects. It was also the form that was the least often indicated as not used. Workgroup was very often used by $31.5 \%$ of the subjects. The third most often employed form was homework. It was often used to create critical thinking by $26.4 \%$ of the subjects. Moreover, one-fifth of the teachers very often developed critical thinking during extracurricular classes. 


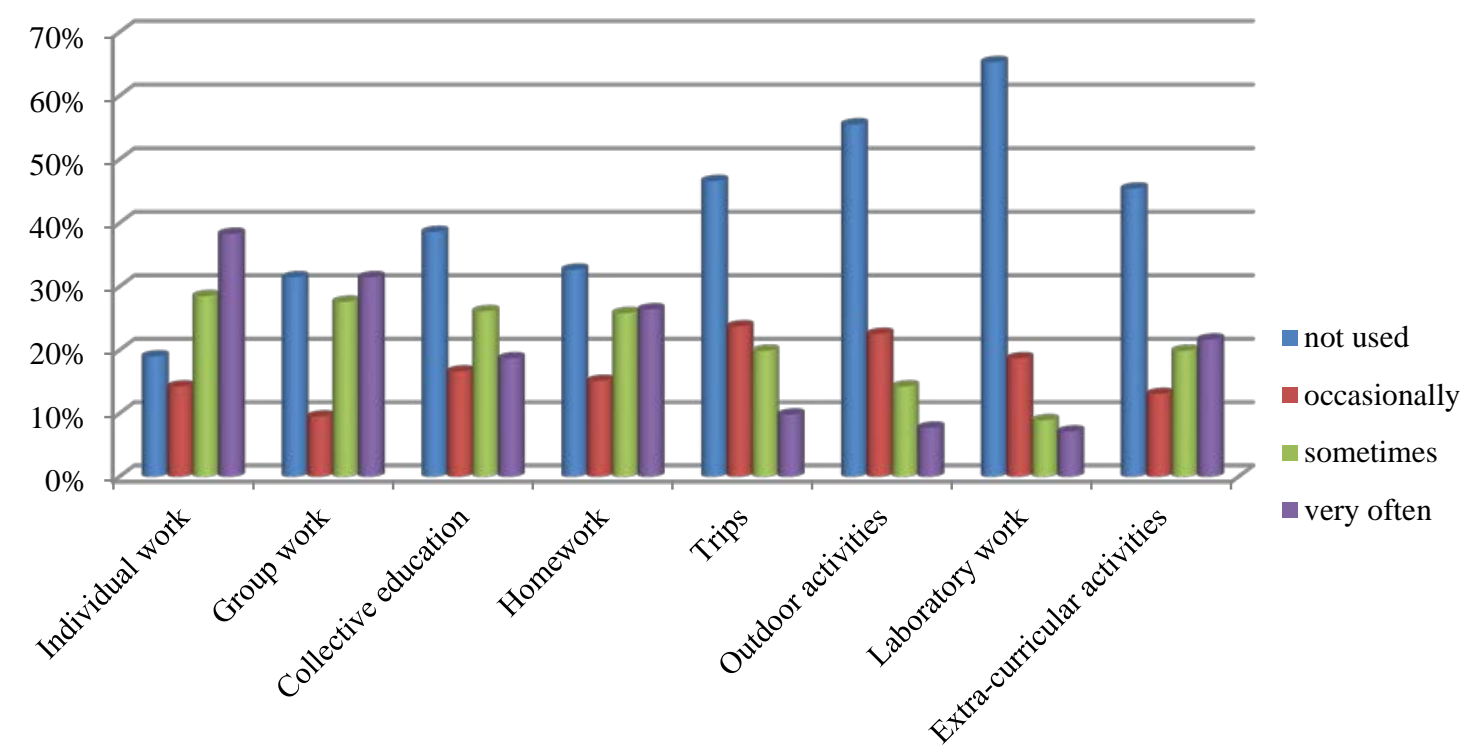

Figure 2. Educational forms most often used by teachers to create the critical thinking competency

\section{Conclusions and recommendations}

The analysis included in the research has demonstrated that teachers in Poland are not prepared sufficiently to shape the critical thinking competency in their students. They fail to take full advantage of the potential of the problem and active-learning methods that enhance independent student activity and develop their competencies. What is more, the teachers used most often only two basic educational forms, individual work and group work and did not employ projects or extramural student activities. Over half of the subjects declared they never held classes outside. Note that competencies are shaped in action and through action. That is why it is so important to empower students to work independently at school and out of school.

In order to ensure that teachers shape the critical thinking competency in students effectively, it is necessary to:

- make teachers aware that in the modern society, the critical thinking competency is indispensable (key) for active and responsible action taking;

- $\quad$ improve methodical competencies of teachers so that they know what educational forms and methods to use in order to develop the critical thinking competency;

- $\quad$ provide students aspiring to become teachers with appropriate training as regards the effective development of the critical thinking competency; 
- $\quad$ encourage teachers to offer extramural activities and employ diverse educational forms;

- $\quad$ include media content in curricula so that young members of the global information society are able to critically evaluate and appropriately react to media information.

\section{References}

Babbie, E. (2013). The Practice of Social Research. Belmont [etc.]: Thomson Wadsworth.

Christensen, B., \& Johnson, L. (2012). Educational research: quantitative, qualitative, and mixed approaches (4th ed.). Thousand Oaks, Calif.: SAGE Publications

Czaja - Chudyba, I. (2013). Myślenie krytyczne w kontekstach edukacji wczesnoszkolnej uwarunkowania nieobecności. Kraków: IMPULS.

Dylak, S. (2003). Koniec „nauczania” czyli nowy paradygmat dydaktyczny [The end of 'teaching', or the new educational paradigm]. In: L. Hurło, D. Klus-Stańska, M. Łojko (Eds.), Paradygmaty współczesnej dydaktyki. Kraków: IMPULS.

Florek, S. (2012). Intuicyjne i krytyczne myślenie moralne w kontekście jego filogenezy i neuropsychologii. [in:] Stupskie Studia Filozoficzne. nr 11/ 2012.

Górniak - Kocikowska, K. (2014). Krytyczne myślenie a krytyczne słuchanie (przyczynek do dydaktyki filozofii) [in:] Analiza i Egzystencja, 25.

Muchacka, B. (2007). Globalna kultura i jej wyzwania dla edukacji [The global culture and educational challenges]. [in:] B. Muchacka (ed.). Edukacja wobec wyzwań globalnego społeczeństwa, Nowy Sącz: Wydawnictwo PWSZ.

Paul, R., \& Edler, L. (2006). Critical Thinking: Tools for Taking Charge of Your Learning and Your Life. New Jersey-Columbus-Ohio: Pearson Education.

Strykowski, W. (2003). Szkoła współczesna i zachodzace w niej procesy [Modern school and its processes] [in:] W. Strykowski, J. Strykowska, J. Pielachowski (eds.). Kompetencje nauczyciela szkoły współczesnej, Poznań. eMPi2.

Wasilewska - Kamińska, E. (2016). Myślenie krytyczne jako cel kształcenia, Warszawa: Wydawnictwo Uniwersytetu Warszawskiego. 